\title{
LIONS-PEETRE TYPE COMPACTNESS RESULTS FOR SEVERAL BANACH SPACES
}

\author{
FERNANDO COBOS* and RAÚl ROMERO ${ }^{\dagger}$
}

\begin{abstract}
Working with interpolation methods associated to polygons, a result of Cobos and Peetre guarantees that the interpolated operator is compact provided all but two restrictions of the operator (located in adjacent vertices) are compact. We characterize here those intermediate spaces that satisfy the conclusion of Cobos-Peetre result for all operators. We also establish some results on rank-one interpolation spaces.
\end{abstract}

Mathematics subject classification (2000): 46B70.

Key words and phrases: Interpolation methods associated to polygons, compactness of interpolated operators, rank-one interpolation spaces.

\section{REFERENCES}

[1] J. BeRGH AND J. LÖFSTRÖM, Interpolation Spaces. An Introduction, Springer, 1976.

[2] B. CARL AND I. STEPhani, Entropy, Compactness and the Approximation of Operators, Cambridge University Press, Cambridge, UK, 1990.

[3] F. COBOS, On the optimality of compactness results for interpolation methods associated to polygons, Indag. Math. 5 (1994) 397-401.

[4] F. Cobos, M. Cwikel And P. Matos, Best possible compactness results of Lions-Peetre type, Proc. Edinb. Math. Soc. 44 (2001) 153-172.

[5] F. Cobos, L. M. FernándeZ-Cabrera, A. MartíneZ And E. Pustylnik, Some interpolation results that are the exclusive property of compact operators, Proc. R. Soc. Edinb. 132A (2002) 317-328.

[6] F. COBOS, P. FERNÁNDEZ-MARTÍNEZ AND A. MARTÍNEZ, Interpolation of the measure of non-compactness by the real method, Studia Math. 135 (1999) 25-38.

[7] F. COBOS, P. FERnÁNDEZ-MARTÍNEZ AND A. MARTÍNEZ, Measure of non-compactness and interpolation methods associated to polygons, Glasgow Math. J. 41 (1999) 65-79.

[8] F. Cobos, P. FernándeZ-MarTíneZ AND T. SCHONBEK, Norm estimates for interpolation methods defined by means of polygons, J. Approx. Theory 80 (1995) 321-351.

[9] F. COBOS, T. KÜHN AND T. SCHONBEK, One-sided compactness results for Aronszajn-Gagliardo functors, J. Funct. Analysis 106 (1992) 274-313.

[10] F. Cobos, A. MANZANO, A. MartíneZ AND P. Matos, On interpolation of strictly singular operators, strictly co-singular operators and related operator ideals, Proc. R. Soc. Edinb. 130A (2000) 971-989.

[11] F. COBOS AND J. PeETRE, Interpolation of compact operators: The multidimensional case, Proc. London Math. Soc. 63 (1991) 371-400.

[12] M. CWIKEL AND S. JANSON, Real and complex interpolation methods for finite and infinite families of Banach spaces, Adv. in Math. 66 (1987) 234-290.

[13] A. A. DMITRIEV, The interpolation of one-dimensional operators, Voronež Gos. Univ. Trudy Naučn. -Issled. Inst. Mat. VGU Vyp. 11 Sb. Statej Funkcional. Anal. i Prilozen 11 (1973) 31-43 (in Russian).

[14] G. Dore, D. GuidetTi And A. Venni, Complex interpolation for $2^{n}$ Banach spaces, Rend. Sem. Mat. Univ. Padova 76 (1986) 1-36.

[15] D. E. Edmunds AND W. D. Evans, Spectral Theory and Differential Operators, Clarendon Press, Oxford, 1987. 
[16] A. FavinI, Su una estensione del metodo d'interpolazione complesso, Rend. Sem. Mat. Univ. Padova (1972) 243-298.

[17] D. L. FERNANDEZ, Interpolation of $2^{n}$ Banach spaces, Studia Math. 45 (1979) 175-201.

[18] D. L. FERNANDEZ, An extension of the complex method of interpolation, Boll. Un. Mat. Ital. (5) B-18 (1981) 721-732.

[19] S. G. KRein, J. I. Petunin And E. M. Semenov, Interpolation of Linear Operators, Amer. Math. Soc., Providence, R.I., 1982.

[20] J. L. Lions and J. Peetre, Sur une classe d'espaces d'interpolation, Inst. Hautes Études Sci. Publ. Math. 19 (1964) 5-68.

[21] L. I. NiKOLOVA, Some estimates of measure of non-compactness for operators acting in interpolation spaces - the multidimensional case, C. R. Acad. Bulg. Sci. 44 (1991) 5-8.

[22] E. PustYLnIK, Minimal and maximal intermediate Banach spaces, Ukrain. Mat. Zhurnal 29 (1977) 129-137. (English transl. in Ukrainian Math. J. 29 (1977) 102-107).

[23] E. I. PUSTYLNIK, Embedding functions and their role in interpolation theory, Abstract Appl. Analysis 1 (1996) 305-325.

[24] G. SPARR, Interpolation of several Banach spaces, Ann. Mat. Pura Appl. 99 (1974) 247-316.

[25] M. F. TEIXEIRA AND D. E. EDMUNDS, Interpolation theory and measure of non-compactness, Math. Nachr. 104 (1981) 129-135.

[26] H. TRIEBEL, Interpolation Theory, Function Spaces, Differential Operators, North-Holland, Amsterdam, 1978. 